\title{
Implementasi Kurikulum 2013 (K-13) dengan Pendekatan Saintifik (Metode 5M) Terhadap Siswa pada Mata Pelajaran Matematika di SMA/MA Negeri Kec. Sape
}

\author{
Edi Mulyadin dan Khaldun Riyadi
}

(C) 2018 JEMS (JurnalEdukasiMatematika dan Sains)

This is an open access article under the CC-BY-SA license (https://creativecommons.org/licenses/bysa/4.0/) ISSN 2337-9049 (print), ISSN 2502-4671 (online)

\begin{abstract}
Abstrak:
Berdasarkan hasil observasi di SMA Negeri 1 Sape diperoleh informasi bahwa masih banyak permasalahan yang berkaitan dengan pelaksanaan Kurikulum 2013 (K-13 di sekolah khususnya jenjang Sekolah Menengah Atas (SMA) sederajat yang statusnya Negeri yang ada di wilayah Kecamatan Sape Kabupaten Bima. Adapun tujuan penelitian ini yaitu untuk mengetahui sejauh mana efektifitas implementasi kurikulum 2013 dengan pendekatan saintifik (metode 5M) terhadap siswa pada mata pelajaran matematika. Menulis laporan penelitian kualitatif. Hasil penelitian menunjukkan bahwa secara umum implementasi K-13 di kecamatan Sape masih kurang efektif karena masih ditemukan beberapa kendala di masing-masing sekolah yang peneliti kunjungi sebagai tempat penelitian, karena memang setiap sekolah memiliki keunggulan dan ciri khas dalam pelaksanaan kegiatan belajar mengajar (KBM) maupun dalam mengimplementasikan kurikulum yang berlaku di sekolah tersebut, salah satu hal yang mempengaruhinya adalah karakter siswa yang berbeda dimasing-masing sekolah.
\end{abstract}

Kata Kunci: Kurikulum 2013; Pendekatan Saintifik; Metode $5 \mathrm{M}$

\section{Pendahuluan}

Pendidikan adalah ranah yang sakral dan diagung-agungkan bagi kebanyakan lapisan masyarakat, banyak stigma masyarakat orang yang berpendidikan atau berilmu adalah orangorang yang mulia dan paling tinggi derajat sosialnya di lingkungan masyarakat, contoh seperti guru, kiyai, ustad, dan masih banyak istilah- istilah gelar yang disematkan pada kaum yang terdidik. Dewasa ini pendidikan cenderung dijadikan objek para stake holder atau pemangku ja-

Edi Mulyadin, STKIP Bima Edi.mulyadin@yahoo.com

Khaldun Riyadi, STKIP Bima Khaldun.Riyadi@yahoo.com

\begin{abstract}
:
Based on observations at Sape 1 Public High School, information was obtained that there were still many problems related to the implementation of the 2013 Curriculum (K-13 in schools, especially the equivalent status of high schools in the State in Sape District, Bima District. The purpose of this study was to determine how far the effectiveness of applying the 2013 curriculum with a scientific approach (5M method) to students in mathematics. Writing a qualitative research report The results showed that in general the implementation of K-13 in Sape District was still ineffective because there were still some obstacles encountered in every school visited by researchers. as a place of research, because indeed each school has advantages and characteristics in the implementation of teaching and learning activities (KBM). As well as in implementing the curriculum that applies in schools, one of the things that influences it is the different character of students in each school.
\end{abstract}

Keywords: 2013 Curriculum; Scientific Approach; 5M Method 
batan di pemerintahan sebagai ranah yang digunakan sebagai alat untuk berpolitik, komersil, dan lainnya. Sehingga tidak heran setiap kontes pemilihan umum digunakan elit politik sebagai alat untuk menarik simpatisan, karena disetiap kampanye politiknya isu yang berkaitan dengan pendidikan dijadikan janji-janji politik. Kemudian ketika sudah terpilih menjadi pemimpin mereka dengan mudahnya membuat berbagai kebijakan yang belum tentu sesuai dengan keadaan sosial masyarakat, salah satunya kebijakan dibidang pendidikan yang tidak efektif adalah dengan mengganti kurikulum yang lama dengan kurikulum yang barudanjanjipolitikpendidikan gratis yang merupakan omong kosong. Padahal semua itu dibebankan kepada dana APBN Negara.

Banyak motif dan alasan yang digunakan elit politik yang berkenaan dengan mengganti kurikulum salah satunya sebagi hasil karya atau inovasi dibidang pendidikan yang dihasilkan oleh pemerintahan yang sedang berkuasa, kemudian sebagai alat ukur kemajuan dibidang pendidikan, dan bidang pendidikan juga sebagai penyumbang beban anggaran APBN negara, dengan besaran 20\% dari anggaran APBN negara, pendidikan merupakan porsi belanja anggaran paling besar yang dilakukan negara. Kenyataan yang kita rasakan saat sekarang apakah pendidikan indonesia mengalami kemajuan?. Kemajuan pasti ada, akan tetapi tolak ukur kemajuan suatu negara salah satunya adalah dibidang pendidikan, dan lebih khusus lagi kemajuan di bidang matematika adalah merupakan tolak ukur kemajuan suatu negara di kancah persaingan global (global competitiveness). Informasi yang diperoleh penulis melalui observasi dan wawancara Tahun 2017 yang dilaksanakan di SMA Negeri 1 Sape pada bulan Agustus sampai dengan bulan Oktober, penulis menyimpulkan masih banyaknya permasalahan yang berkaitan dengan Kurikulum 2013. Temuan saya masih berlakunya kurikulum tingkat satuan pendidikan (KTSP) 2006 di kelas XII yang notabene di kelas X dan XI sudah diberlakukan Kurikulum 2013 (K13), Pada hal kurikulum ini dicanangkan oleh pemerintah sudah berjalan selama 4 tahun dan masih banyak sekali kekurangan-kekurangan yang dihadapi oleh sekolah-sekolah khususnya jenjang Sekolah Menengah Atas (SMA) sederajat yang statusnya Negeri yang ada di wilayah Kecamatan Sape Kabupaten Bima, mulai dari kompetensi, sarana dan perasarana dan daya dukung pendidik dan peserta didik dari masing-masing sekolah.

Berawal dari masalah diatas penulis mencoba mengadakan penelitian tentang “Implementasi Kurikulum K-13 Dengan Pendekatan Saintifik (Metode 5M)terhadap siswa pada mata pelajaran matematika di SMA/MA Negeri di Kecamatan Sape Kabupaten Bima Tahun 2018". Berkaca dari kekurangan yang disebutkan diatas tentunya dapat diminimalisir dengan tetap menjalankan kurikulum 2013 (K13) dengan pendekatan saintifik (5M) yaitu (observing (mengamati), questioning (menanya), mengumpulkan informasi/ eksperimen, mengasosiasikan/ mengolah informasi, dan mengkomunikasikan) akan dirasa sangat berpengaruh pada efektifitas pembelajaran siswa pada mata pelajaran matematika di SMA / MA Negeri Kecamatan Sape Kabupaten Bima.

\section{Metode}

Jenis penelitian ini merupakan penelitian survey. Menurut Prasetyo (2008:49) penelitian survey merupakan penelitian yang menggunakan lembar observasi dan wawancara sebagai instrumen penelitiannya. Dalam penelitian ini lembar observasi dan pedoman wawancara yang penulis gunakan berisikan beberapa pertanyaan tentang data sekolah di SMA Negeri se-Kecamatan Sape yang berkenaan dengan implementasi kebijakan kurikulum K13 dengan pendekatan saintifik (metode 5M) pada mata pelajaran matematika. 
Penelitian ini menggunakan pendekatan kualitatif sedangkan desain/jenis penelitian yang digunakan adalah desain penelitian deskriptif. Penelitian kualitatif ditujukan untuk memahami fenomena-fenomena sosial dari sudut perspektif partisipan. Partisipan adalah orangorangyang diajak berwawancara, diobservasi, dimintamemberikan data, pendapat, pemikiran, persepsinya (Sukmadinata, 2006).

\section{Hasil dan Pembahasan}

\section{Hasil}

\section{Efektivitas Implementasi Kebijakan Kurikulum 2013 Pada Mata Pelajaran Matematika} Di SMA/MA Negeri Kecamatan Sape.

Bedasarkan hasil wawancara terhadap wakasek, guru matematika dan siswa peneliti mendapatkan informan beragam mengenai efektivitas kebijakan kurikulum 2013 pada mata pelajaran matematika di SMA/MA Negeri Kecamatan Sape, berikut hasil wawancara yang didapatkan peneliti;

a. SMA Negeri 1 Sape

Kepala Sekolah SMAN 1 Sape JH menuturkan, “ Penelitian ini meneliti tentang efektivitas maka bila perlu diadakan penelitian perbandingan dengan mata pelajaran yang lain sehingga penelitian didapat hasil beragam dan tidak terpusat pada mata pelajaran matematika untuk mengetahui efektifitas implementasi kurikulum 2013 di SMAN 1 Sape. Kemudian hasi wawancara dengan " $\mathrm{JH}$ " dipertegas kembali oleh pendapat Koordinator Pembina non akademik yaitu "MY" beliau sebagai guru olahraga; " Sejak Kurikulum 2013 diberlakukan di sekolah ini pada tahun 2013 bertahap sampai dengan sekarang di seluruh rombel di SMAN 1 Sape, saya berpendapat Kurikulum 2013 dengan pendekatan saintifik metode 5M sangat bagus karena siswa lebih antusias dalam pembelajaran lebih-lebih pada jam pelajaran olahraga. Beliau menambahkan efek dari kurikulum 2013 sangat dirasakan adanya perubahan sikap pada siswa". Kemudian guru matematika "S". menjelaskan, "Di SMAN 1 Sape diberlakukan kurikulum 2013. Pemberlakuan 2013 di SMAN 1 Sape dimulai pada tahun 2014/2015. Setelah satu semester berjalan, Kurikulum 2013 ditarik kembali oleh pemerintah Provinsi untuk direvisi kembali dan kemudian diberlakukan kembali pada tahun pelajaran 2016/2017 sampai dengan sekarang, Pada kurikulum 2013 mata pelajaran matematika ada dua pembagian jurusan yaitu matematika wajib dan matematika peminatan (IPA). Matematika wajib membahas materi dasar, sedangkan matematika peminatan membahas materi pengembangan, kemudian diharapkan siswa berpikir konkrit dengan mengaitkan pada kehidupan nyata di sekelilingsiswa pada materi pembelajaran, sehingga siswa lebih semangat dan antusias dalam belajar.

Hal tersebut diatas didukung oleh hasil wawancara terhadap siswa yakni disampaiakan oleh ketua Osis SMAN 1 Sape “NAM” sebagai berikut ; "Menurut saya efek dari kurikulum 2013 ini berdampak positif dan negatif. Positifnya yaitu siswa menjadi lebih aktif dan inovatif serta lebih leluasa untuk mengungkapkan pendapat, negatifnya yaitu berdampak pada siswa yang mentalnya kurang bagus, karena pada metode ini lebih menonjolkan siswa yang kemampuannya diatas rata-rata."

b. SMA Negeri 2 Sape

Wakasek Kurikulum SMA Negeri 2 Sape “F” menuturkan kurikulum 2013 sudah diberlakukan di seluruh rombel yaitu di kelas X,XI, dan XII. Kemudian diberlakukan sejak tahun 2015 untuk kelas X. Adapun “F” menuturkan bahwasanya kurikulum 2013 lebih mengedepankan karakter siswa dan yang diutamakan akhlak, pada saat jam pertama (literasi) , 
siswa lebih aktif dalam proses KBM (Kegiatan Belajar Mengajar), "F" juga menuturkan Kurikulum 2013 pada matapelajaran matematika sangat bagus untuk diterapkan metode 5Mnya, namun kendala dirasakan apabila kemampuan peserta didik kurang. Sama halnya dengan Guru Kelas SMA Negeri 2 Sape “ES” juga menuturkan implementasi kurikulum 2013 dengan pendekatan saintifik (Metode 5M) berhubung pendekatan ini merupakan salah satu pendekatan yang menekan pentingnya penggunaan proses berfikir ilmiah sesuai tingkatan perkembangan anak, dimana anak-anak dituntut untuk mencari tahu dari berbagi informasi seperti umpan balik tidak sesuai dengan harapan kurikulum 2013. Anak-anak masih fokus untuk menerima informasi, tanpa mencoba terlibat aktif dalam proses pembelajaran. Dan sejauh ini belum nampak efek yang memuaskan dari kurikulum 2013 khususnya pendekatan saintifik karena kebanyakan anak masih fokus pada cara belajar lama dan hanya anak-anak yang memiliki keinginan kemauan belajar yang tinggi saja yang menikmati manfaat dari pendekatan ini. Hal diatas juga diutarakan Ketua Osis "NPP", menurutnya kurikulum 2013 lebi mengutamakan keaktifan siswa, guru hanya memberikan materi mata pelajaran yang untuk dipahami dan dipelajari sendiri ole siswa dan harus di presentasikan, intinya Kurikulum 2013 siswa harus lebih aktif. "NPP' juga mengatakan "kurikulum 2013 berlaku di mata pelajaran matematika di kelas kami" Kemudian "NPP" mengatakan kesan-kesannya dalam belajar pada aat mata pelajaran matematika dengan menggunakan kurikulum 2013 sebagai berikut, " mata pelajaran matematika dalam kurikulum 2013 sangatlah menyenangkan karena siswa lebih aktif dalam bertanya, menawab, dan mempresentasikan soal atau jawabannya".

c. SMA Negeri 3 Sape.

Wakasek Kurikulum SMA Negeri 3 Sape "MA" menuturkan kurikulum 2013 sudah diberlakukan di seluruh rombel yaitu di kelas X,XI, dan XII. Kemudian diberlakukan sejak tahun 2015 untuk kelas X. Adapun "MA" menuturkan bahwasanya kurikulum 2013 lebih mengedepankan karakter siswa dan yang diutamakan akhlak, siswa dituntut lebih aktif dalam proses KBM (Kegiatan Belajar Mengajar), "MA” juga menuturkan Kurikulum 2013 pada mata pelajaran matematika sangat bagus untuk diterapkan metode 5M-nya, namun kendala dirasakan apabila kemampuan peserta didik kurang. Sama halnya dengan Guru Kelas SMA Negeri 3 Sape "F" juga menuturkan implementasi kurikulum 2013 dengan pendekatan saintifik (Metode 5M) berhubung pendekatan ini merupakan salah satu pendekatan yang menekan pentingnya penggunaan proses berfikir ilmiah sesuai tingkatan perkembangan anak.

Hal diatas juga diutarakan Ketua Osis "MA", menurutnya kurikulum 2013 lebi mengutamakan keaktifan siswa, guru hanya memberikan materi mata pelajaran yang untuk dipahami dan dipelajari sendiri ole siswa dan harus di presentasikan, intinya Kurikulum 2013 siswa harus lebih aktif. "MA' juga mengatakan "kurikulum 2013 berlaku di mata pelajaran matematika di kelas kami" Kemudian "MA" mengatakan kesan-kesannya dalam belajar pada aat mata pelajaran matematika dengan menggunakan kurikulum 2013 sebagai berikut," mata pelajaran matematika dalam kurikulum 2013 sangatlah menyenangkan karena siswa lebih aktif dalam bertanya, menawab, dan mempresentasikan soal atau jawabannya".

d. MA Negeri 2 Sape

Wakasek Kurikulum MA Negeri 2 Sape “N” menuturkan kurikulum 2013 sudah diberlakukan di seluruh rombel yaitu di kelas X,XI, dan XII. Kemudian diberlakukan sejak tahun 2015 untuk kelas X. Adapun "N" menuturkan bahwasanya kurikulum 2013 lebih mengedepankan karakter siswa dan yang diutamakan akhlak, pada saat jam pertama (literasi), siswa lebih aktif dalam proses KBM (Kegiatan Belajar Mengajar), "N" juga menuturkan Kurikulum 2013 pada matapelajaran matematika sangat bagus untuk diterapkan metode 5M- 
nya, namun kendala dirasakan apabila kemampuan peserta didik kurang.

Sama halnya dengan Guru Kelas MA Negeri 2 Sape "AS" juga menuturkan implementasi kurikulum 2013 dengan pendekatan saintifik (Metode 5M) berhubung pendekatan ini merupakan salah satu pendekatan yang menekan pentingnya penggunaan proses berfikir ilmiah sesuai tingkatan perkembangan anak, dimana anak-anak dituntut untuk mencari tahu dari berbagi informasi seperti umpan balik tidak sesuai dengan harapan kurikulum 2013. Anak-anak masih fokus untuk menerima informasi, tanpa mencoba terlibat aktif dalam proses pembelajaran. Dan sejauh ini belum nampak efek yang memuaskan dari kurikulum 2013 khususnya pendekatan saintifik karena kebanyakan anak masih fokus pada cara belajar lama dan hanya anak-anak yang memiliki keinginan kemauan belajar yang tinggi saja yang menikmati manfaat dari pendekatan ini.

Hal diatas juga diutarakan Ketua Osis "W", menurutnya kurikulum 2013 lebi mengutamakan keaktifan siswa, guru hanya memberikan materi mata pelajaran yang untuk dipahami dan dipelajari sendiri ole siswa dan harus di presentasikan, intinya Kurikulum 2013 siswa harus lebih aktif. "W' juga mengatakan "kurikulum 2013 berlaku di mata pelajaran matematika di kelas kami" Kemudian "W" mengatakan kesan-kesannya dalam belajar pada aat mata pelajaran matematika dengan menggunakan kurikulum 2013 sebagai berikut, " mata pelajaran matematika dalam kurikulum 2013 sangatlah menyenangkan karena siswa lebih aktif dalam bertanya, menjawab, dan mempresentasikan soal atau jawabannya".

Dari berbagai hasil wawancara di 4 sekolah menengah negeri di kecamatan Sape peneliti dapat menyimpulkan implementasi kurikulum 2013 khususnya di kecamatan Sape secara umum pelakanaannya sudah baik akan tetapi masih ditemukan beberapa kendala yang tentunya harus terus dibenahi dan ditingkatkan oleh seluruh steakholder yang ada di kecamatan Sape, seperti dari sarana prasarana, daya dukung, intake para steakolder, sehingga hal tersebut menyebabkan

2. Hambatan Implementasi Kurikulum K-13 dengan Pendekatan Saintifik (Metode 5M) Terhadap Siswa Pada Mata Pelajaran Matematika di SMA/ MA Negeri Kecamatan Sape.

a. SMA Negeri 1 Sape.

Bedasarkan hasil wawancara dengan Guru Mata Pelajaran Matematika "S" peneliti memperoleh tanggapan sebagai berikut; "Hambatan yang terjadi adalah sosialisasi kurikulum 2013 yang belum merata dan revisi yang terus menerus dilakukan".(WGMPM SMAN 1 Sape).Kemudian ditambahkan oleh Ketua OSIS SMA Negeri 1 Sape "NAM", "Kesulitan yaitu pada saat KBM saat guru menjelaskan dengan penjelasan yang kurang memahami siswa karena cara mengajar kurang efektif".(WKOsis SMAN 1 Sape, 2 Agustus 2018). Hal ini dialami oleh siswa hampir di semuasekolah SMA/MA Negeri Kecamatan Sape.

b. SMA Negeri 2 Sape.

Kemudian "ES" menambahkan, " Hambatan yang paling besar kami selaku guru adalah susah dalam membangkitkan semangat siswa unntuk bertanya, sehingga pada saat proses belajar masih saja guru yang mendominasi. (WGMPM SMAN 2 Sape, 11 Agustus 2018)

Kemudian Ketua OSIS SMA Negeri 2 Sape "NPP” menambahkan "Kesulitan yaitu pada saat KBM saat guru menjelaskan dengan penjelasan yang kurang memahami siswa karena cara mengajar kurang efektif" (WKOsis SMAN 2 Sape, 2 Agustus 2018). Hal ini dialami oleh siswa hampir di semua sekolah SMA/MA Negeri Kecamatan Sape. 
c. SMA Negeri 3 Sape.

Kemudian "F" mengatakan, " Hambatan yang paling besar kami selaku guru adalah susah dalam membangkitkan semangat siswa untuk aktif bertanya, sehingga pada saat proses belajar tidak ada fit back dari siswa dan guru yang mendominasi. (WGMPM SMAN 3 Sape)

Kemudian Ketua OSIS SMA Negeri 3 Sape “MA" menambahkan “Kesulitan yaitu pada saat KBM saat guru menjelaskan dengan penjelasan yang kurang memahami tingkat kemampuan siswa karena cara mengajar dan metode kurang efektif".(WKOsis SMAN 3 Sape, 2 Agustus 2018). Hal ini dialami oleh siswa hampir di semuasekolah SMA/MA Negeri Kecamatan Sape.

d. MA Negeri 2 Bima.

Hal diatas serupa juga disampaikan oleh guru mata pelajaran matematika di MAN 2 Bima yaitu "AS", "Kurikulum 2013 berjalan dengan baik di MAN 2 Bima (MAN Sape) dengan adanya kurikulum 2013 siswa bisa belajar berfikir dengan cermat. (WGMPM MAN 2 Bima, 9 Agustus 2018).

Dari beberapa hasil wawancara diatas peneliti dapat menyimpulkan, hambatan yang terjadi di masing sekolah hampir sama dan diharapkan dari hambatan tersebut di atas dapat diupayakan solusi yang konkrit dan efektif dalam pengimplementasiannya.

3. Solusi Terhadap Hambatan Implementasi Kurikulum K-13 Dengan Pendekatan Saintifik (Metode 5M) Terhadap Siswa Pada Mata Pelajaran Matematika Di SMA/MA Negeri Kecamatan Sape Kabupaten Bima.

a. SMA Negeri 1 Sape.

Solusi yang ditawarkan Guru Mata Pelajaran Matematika SMA Negeri 1 Sape "S" mengatakan solusi atas hambatan yang terjadi pada kurikulum 2013 dengan melakukam Musyawarah Guru Mata Pelajaran (MGMP) Matematika" (WGMPM SMAN 1 Sape). Ketua OSIS SMA Negeri 1 Sape "NAM", "dengan cara menerapkan metode yang lebih menarik perhatian siswa, misalnya seperti memberi kuis yang merata kepada seluruh siswa".(WKOsis SMAN 1 Sape).

b. SMA Negeri 2 Sape.

Solusi yang ditawarkan Guru Mata Pelajaran Matematika SMA Negeri 2 Sape "ES", dikelas biasanya memberi tugas kelompok dan pada saat diskusi siswa saling melempar dan menanggapi masalah secara bergantian dengan begitu siswa dilatih untuk mengamati menanya, mencoba, menalar, kemudian mengkomunikasikan".(WGMPM SMAN 2 Sape, 15 Agustus 2018). Kemudian Wakil Kepala Sekolah Kurikulum SMAN 2 Sape "F”, menambahkan "pembelajaran dengan banyak menggunakan buku refrensi dan berbasis teknologi (menggunakan LCD)". (WWKSK SMAN 2 Sape, 15 Agustus 2018). Hal tersebut diperkuat Ketua OSIS SMAN 2 Sape "NPP" yaitu dengan "lebih banyak bertanya dan sering membaca buku paket siswa yang ada di perpustakaan".(WKOsis SMAN 2 Sape).

c. SMA Negeri 3 Sape.

Solusi yang ditawarkan Guru Mata Pelajaran Matematika SMA Negeri 3 Sape "F", dikelas biasanya memberi tugas kelompok dan pada saat diskusi siswa saling melempar dan menanggapi masalah secara bergantian dengan begitu siswa dilatih untuk mengamati menanya, mencoba, menalar, kemudian mengkomunikasikan".(WGMPM SMAN 3 Sape) Kemudian Wakil Kepala Sekolah Kurikulum SMAN3 Sape "MA", menambahkan "pembelajaran dengan banyak menggunakan buku refrensi dan berbasis teknologi (menggunakan LCD)" . (WWKSK SMAN 3 Sape). Hal tersebut diperkuat Ketua OSIS SMAN 3 Sape "MA" yaitu dengan "lebih banyak bertanya dan sering membaca buku paket siswa yang ada di perpustakaan dan 
browsing materi pelajaran melalui internet".(WKOsis SMAN 3 Sape).

d. $\quad$ MA Negeri 2 Bima (MAN Sape)

Wakil Kepala Sekolah Kurikulum "N" mengatakan solusi pada hambatan kurikulum 2013 dapat diperoleh dengan guru membuat Modul sendiri, dan memperbanyak Lembar Kerja Siswa (LKS)". (WWKK MAN 2 Bima). Guru kelas MAN 2 Bima “AS” mengatakan dengan membentuk dan menggiatkan Musyawarah Guru Mata Pelajaran Matematika (MGMPM) khususnya di kecamatan Sape, Sementara Ketua OSIS MAN 2 Bima "W" mengatakan "dengan mengganti guru yang lebih profesional dan lebih menguasai materi pelajaran". (WKOsis MAN 2 Bima).

Hasil wancara diatas di perkuat kembali oleh hasil pengisian angket terhadap 24 responden yaitu guru matematika yang ada di SMA/MA Negeri Kecamatan Sape dari 24 reponden mengisi angket yang berjumlah 23 pertanyaan pilihan ganda $a, b, c, d$ merespon Sangat Baik (SB) pada pertanyaan sebanyak 90 kali, Baik (B) pada pertanyaan sebanyak 338 kali, Tidak Baik (TB) pada pertanyaan sebanyak 44 kali, dan Sangat Tidak Baik (STB) pada pertanyaan sebanyak 4 kali Secara umum hasil wawancara dengan beberapa responden tidak jauh berbeda. Dengan pelaksanaan dan hambatan solusi yang beragam didapat melalui wawancara diberbagai sekolah peneliti menyimpulakan bawasanya pelaksanaan kurikulum 2013 di kecamatan Sape sudah baik, akan tetapi dari hasil yang diperoleh pada setiap tahapan penelitian diatas masih ada kekurangan yang terjadi, lama waktu usia pelaksanaan kurikulum 2013 di setiap sekolah, sarana prasarana yang kurang memadai, tidak keseuaian dana operasional sekolah yang cenderung salah sasaran dan kurang efektif, daya dukung sumber daya manusia yang masih kurang, dsb.

\section{Pembahasan.}

1. Efektivitas Kebijakan Kurikulum 2013 Pada Mata Pelajaran Matematika di SMA/MA Negeri Kecamatan Sape.

Kurikulum 2013 hanya menekankan pada suatu capaian aspek terukur secara kuantitatif yaitu aspek kognitif, karena dalam kurikulum ini masih diberlakukan ujian nasional (UN). Undang-undang Nomor 20 Tahun 2003 tentang Sisdiknas pasal 36 ayat (3) menyatakan bahawa kurikulum pendidikan nasional haruslah memperhatikan : a) Peningkatan iman dan takwa; b) peningkatan akhlak mulia; c) peningkatan potensi, kecerdasan, dan minat peserta didik; d) keragaman potensi daerah dan lingkungan; e) tuntutan pembangunan daerah dan nasional; $\mathrm{f}$ ) tuntutan dunia kerja; g) perkembangan ilmu pengetahuan, teknologi, dan seni; h) agama; i) dinamika perkembangan global; dan j) persatuan nasional dan nilai kebangsaan. Berdasarkan hasil wawancara, studi dokumen dan observasi atau pengamatan langsung dilapangan, maka diketahuai bahwa aspek-aspek tersebut terkesan hanya dititipkan pada mata pelajaran tertentu dan sulit untuk diukur dan diketahui tingkat keberhasilannya jika evaluasi dan penilaian hanya dilakukan dengan mengukur aspek kognitif saja melaui ujian nasional. Dengan demikian, perubahan kurikulum hendaknya mempertimbangkan beberapa hal, diantaranya sebagai berikut:

a. Perubahan kurikulum sebagai sebuah kebijakan harus didasarkan pada pengkajian yang mendalam tentang masa depan kebijakan, bersifat konstruktif dan antisipasif, adanya dukungan dari semua stakeholder pendidikan, maupun dampak dan kontribusi dalam pengembangan dan pencapaian tujuan pendidikan nasional.

b. Pengembangan kurikulum harus mengakomodasikan berbagai aspek yang diamanatkan oleh Undang-Undang Sisdiknas secara seimbang, tidak dengan mengukur pencapaian aspek kognitif saja, tetapi juga memperjelas pengukuran aspek sikap dan 
keterampilan. Selama ini aspek sikap dan keterampilan cenderung terpinggirkan.

c. Pengembangan kurikulum harus memperhatikan perkembangan psikologis siswa. Dalam pelaksanaan pembelajaran masih kurang memberikan perhatian khusus terhadap karakteristik dan latar belakang siswa. Pembelajaran masih diseragamkan, belum bisa mengembangkan kurikulum yang menerima keanekaragaman.

2. Hambatan Implementasi Kurikulum K-13 dengan Pendekatan Saintifik (Metode 5M) TerhadapSiswa Pada Mata Pelajaran Matematika di SMA / MA Negeri Kecamatan Sape.

Menteri Pendidikan dan Kebudayaan, Muhammd Nuh menegaskan bahwa kurikulum 2013 ini lebih ditekankan pada tiga ranah kompetensi, yaitu kompetensi berbasis pengetahuan, sikap, dan keterampilan dan penguatan karakter. Kurikulum ini menuntut kemampuan guru untuk memaksimalkan kemampuan nalar dan keilmuannya karena pembelajaran bersifat tematik terpadau sehingga mau tidak bisa guru harus memadukan ilmu pengetahuan yang ada dalam mata pelajaran lain untuk mencapai kompetensi dasar yang diajarkan.

Hasil uraian wawancara dengan Wakasek, guru matematika, serta siswa SMA/MA Negeri di atas dengan didukung data dalam dokumen diketahui Secara garis besar Implementasi Kurikulum 2013 di kecamatan Sape secara umum masih kurang efektif karena masih ditemukan beberapa kendala di masing-masing sekolah yang peneliti kunjungi sebagai tempat penelitian seperti ; sarana prasarana, kesejahteraan guru, dan motivasi belajar siswa yang masih kurang memadai. Akan tetapi peneliti berasumsi bahwa keterbatasan bukan hal yang menghalangi pendidik dan peserta didik dalam mengembangkan pembelajaran dan terus berprestasi, hal itu diperkuat karena memang setiap sekolah memiliki keunggulan dan ciri khas dalam pelaksanaan kegiatan belajar mengajar (KBM) maupun dalam mengimplementasikan kurikulum yang berlaku disekolah tersebut ini dapat dilihat dari karekter siswa yang berbeda dimasingmasing sekolah yang ada di Kecamatan Sape". Hal ini diperkuat oleh peneliti dengan beberapa teori-teori. Pendidikan mestinya harus menanam benih-benih keragaman, pluralisme, dan multikultural, bukan keseragaman dan monokultural (Darmaningtyas, 2005). Teori Grindle mengungkapkan bahwa salah satu faktor yang mempengaruhi implementasi kebijakan adalah isi kebijakan. Isi kebijakan menurut Grindle harus melihat Interns Affected (kepentingankepentingan yang mempengaruhi dalam hal ini program yang dilakukan).

\section{Solusi Terhadap Hambatan Implementasi Kurikulum K-13 Dengan Pendekatan Saintifik (Metode 5M) Terhadap Siswa Pada Mata Pelajaran Matematika Di SMA / MA Negeri Kecamatan Sape Kabupaten Bima.}

Kecerdasan otak bukanlah hal yang utama dalam pendidikan akan tetapi bagaimana peserta didik memiliki budi pekerti mulia yang merupakan tujuan utama dalam pendidikan. Sehingga peserta didik yang nantinya menjadi orang yang cerdas dantidakakan menyalah gunakan kecerdasanya untuk menipu orang lain. Upaya orang tua dalam memberikan layanan pendidikan yang terbaik bagi anak-anak, para orangtua berusaha memilih pendidikan yang sesuai dengan minat dan kebutuhan belajar mereka. Akan tetapi realita yang ada menunjukkan ketidak efektifan dan ketidak efisienan sebagaian besar proses belajar pada Pendidikan Formal. Bertalian dengan aturan baru yang digariskan Departemen Pendidikan Nasional, yaitu penyusunan kurikulum didasarkan pada Standar Kompetensi Lulusan (SKL) dan Standar Isi (SI) hasil rumusan Badan Standar Nasional Pendidikan (BSNP), sekolah/madrasah, sejak SD/MI, SMP/MTs, hingga SMA/MA (sederajat) dapat menyusun kurikulum sendiri (Idi, 2007). 


\section{Simpulan}

Bedasarkan hasil dan pembahasan dari penelitian kualitatif karya tulis ini, maka dapat disimpulkan bahwa:

1. Implementasi kurikulum 2013 dengan pendekatan saintifik (Metode 5M) terhadap siswa pada mata pelajaran matematika di SMA/MA Negeri Kecamatan Sape Tahun Ajaran 2018/2019, kurang efektif karena disebabkan beberapa faktor yaitu faktor internal dan faktor eksternal.

2. Faktor internal di sini berasal dari informan yaitu siswa, tenaga pengajar dan para stekholder. Sedangkan faktor eksternal yaitu berupa fisik yang nampak dan dapat menunjang segala aktifitas dalam mengimplementasikan kurikulum dimasing- masing satuan pendidikan (sekolah);

a. Sarana Prasarana penunjang untuk belajar yang belum memadai seperti ruangan laboatorium dll.

b. b. Hampir 90\% guru-guru yang mengajar dimasing-masing sekolah masih berstatus guru honorer dan merangkap mengajar di dua sekolah yang berbeda dengan harapan mendapat jam mengajar dan honor lebih, hal ini tentu mempengaruhi kinerja guru dan proses belajar mengajar menjadi tidak efektif.

c. Kurangnya perhatian pemerintah untuk memberikan solusi-solusi yang konkret dan lebih banyak melaksanakan kegiatan-kegiatan yang sifatnya ceremonial yang kurang efektif.

d. Motivasi belajar siswa yang masih rendah pada mata pelajaran sains seperti ; matematika, IPA, IPS, Kebahasaan, dll. Mereka lebih menyukai mata pelajaran yang non sains, seperti Olahraga dan Seni.

3. Solusi terhadap hal yang terjadi dapat dilakukan dengan berbagai hal sebagai berikut:

a. Kekurangan sarana prasarana dapat diminimalisir dengan membuat kesepakatan kerjasama dengan perguruan tinggi dan instansi-instansi yang dapat menunjang kegiatan belajar mengajar yang ada di wilayah kota/kabupaten Bima, misal sekolah meminjam fasilitas laboratorium perguruan tinggi tersebut, melakukan studi tour dll.

b. b. Kesejahteraan guru honorer lebih diperhatikan dengan mengangkat guru honorer menjadi pegawai negeri sipil secara bertahap dan lebih memperbanyaktunjangantunjangan guru yang sifatnya menunjang dan meringankan kebutuhan-kebutuhan guru honorer.

c. c. Dengan terpenuhinya dua point diatas kemudian guru dapat menggunakan metode pemebelajaran yang kreatif dan inovatif.tidak monoton dalam menggunakan metode pembelajaran sehingga siswa lebih termotivasi.

\section{Daftar Rujukan}

Andang. 2014. Kebijakan Kurikulum.Malang: UMM Press Boeree, Dr.C. George. 2016. Personality Theories Melacak Kepribadian Anda Bersama Psikologi Dunia. Yogyakarta : Prisma Sophie.

Fadillah, Muhammad ; Khorida, Lilif Mualifatul. 2016. Pendidikan Karakter Anak Usia Dini :Konsep E Aplikasinya dalam PAUD. Yogyakarta : Ar-Ruzz Media. 
Hidayat, Gufron. 2013. Move Mood On Hidupkan Potensi Tanpa Tapi, Sukses Tanpa Tepi. Depok : Mutiara Allamah Utama.

Idris, MeityH. 2014. Peran Guru dalam Mengelola Keberbakatan Anak. Jakarta : PT. Luxima Metro Media

Ilahi, Muhammad Takdir. 2016. Pendidikan Inklusif, Konsep \& Aplikasi.Yogyakarta : Ar-Ruzz Media.

Mulyadin,Edi. 2010. "Efektivitas Kebijakan Pendidikan Budi Pekerti Pada Komunitas Homeschooling Sekolah Dolan". Tesis Pasca Sarjana Jurusan Kebijakan Kurikulum UnivesitasMuhamadiyah Malang.

Novi, A. .2014. True Spirit Bacharuddin Jusuf Habibie. Yogyakarta : Lamafa Publika

Palmer, JoyA. 2015. Ide-Ide Berlian 50 Pakar Pendidikan Kontemporer Paling Berpengaruh di Dunia Pendidikan Modern.Yogyakarta : IRCiSoD.

Risaldy, Sabil. 2015. Manajemen Pengelolaan Sekolah Usia Dini. Yogyakarta : PT. Luxima Metro Media.

Rifa'i, Muhamad. 2016. Sejarah Pendidikan Nasional dari Masa Klasik Hingga Modern. Yogyakarta: Ar-Ruzz Media.

Rosyadi, Imron. 2016. RA Kartini Biografi Singkat 1879-1904.Yogyakarta: Ar-Ruzz Media.

Susilo, Taufik Adi. 2016. Lebih Dekat Dengan SBY. Yogyakarta : Garasi House of Book.

Sopyan, Imam ; Cahyana, Cucu. 2015. Super RPUL Rangkuman Pengatahuan Umum Lengkap+UUD 1945EAmandemen.Depok : Mutiara Allamah Utama.

Sugiyono. 2012. Metode Penelitian Kuantitatif, Kualitatif dan RED. Bandung : ALFABETA. Undang - Undang Dasar (UUD) 1945 Negara Republik Indonesia Tahun1945. dkk.

Undang-Undang Sisdiknas Nomor 20 Tahun 2003. https://www.scribd.com/doc/149506006/Apa-ItuTimss. Diunduh 28 juli 2018 pukul

11.21 Wita. https://dhanymatika.wordpress.com/2013/09/02/pisa-programme-internationale-for-studentassesment/. Diunduh 28 juli 2018 pukul 11.21 Wita 